Research Article

\title{
Experimental Study on a New Reinforcement Method for Multilayer Industrial Building's Vibration
}

\author{
Kaizhong Xie, ${ }^{1,2,3}$ Hongwei Wang $\left(\mathbb{D},{ }^{1}\right.$ Jianxi Zhou $\mathbb{D D}^{1}{ }^{1}$ Xiao Luo, ${ }^{1}$ and Miao Yue ${ }^{1}$ \\ ${ }^{1}$ College of Civil Engineering and Architecture, Guangxi University, Nanning 530004, Guangxi, China \\ ${ }^{2}$ Key Laboratory of Ministry Education of Engineering Disaster Prevention and Structural Safety, Guangxi University, \\ Nanning 530004, Guangxi, China \\ ${ }^{3}$ Guangxi Key Laboratory of Engineering Disaster Prevention and Structural Safety, Guangxi University, Nanning 530004, \\ Guangxi, China
}

Correspondence should be addressed to Hongwei Wang; 779348631@qq.com

Received 10 July 2019; Revised 16 September 2019; Accepted 25 October 2019; Published 20 November 2019

Academic Editor: Emanuele Brunesi

Copyright ( 2019 Kaizhong Xie et al. This is an open access article distributed under the Creative Commons Attribution License, which permits unrestricted use, distribution, and reproduction in any medium, provided the original work is properly cited.

In order to study a new reinforcement method for multilayer (4 layers) industrial building's vibration, firstly, a new reinforcement method using a short-pier shear wall was put forward. Secondly, an engineering example of a multilayer industrial building with abnormal vibration was introduced. A three-dimensional finite element model of multilayer industrial building was established, and field vibration test was carried out. Test results showed that abnormal vibration of industrial building was caused by resonance between machines and multilayer industrial building. Finally, multilayer industrial building was reinforced by a new reinforcement method, and vibration experiment was carried out after reinforcement. The results show that the new reinforcement method has a good reinforcement effect. Strength and stiffness of multilayer industrial building were obviously improved, and natural frequency of industrial building in the length direction increased from $2.45 \mathrm{~Hz}$ to $5.87 \mathrm{~Hz}$, natural frequency of industrial building in the width direction increased from $2.94 \mathrm{~Hz}$ to $7.83 \mathrm{~Hz}$, frequencies of machines and frequencies of multilayer industrial building were not in resonance range, acceleration and velocity vibration characteristics of multilayer industrial building were improved, which can provide reference for the reinforcement of multilayer industrial building with a similar structural configuration.

\section{Introduction}

Multilayer industrial building is widely used in civil engineering, as it has a compact structural arrangement and can make full use of land resource. However, more and more machines were installed in multilayer industrial building, vibration problem [1] of multilayer industrial building was brought about. In addition, the vibration of industrial buildings during earthquakes is also worthy of attention. The actual damage of industrial buildings in various earthquakes is the destruction of reinforced concrete columns and nonstructural components, such as enclosure structural roofs. The damage of reinforced concrete columns is mainly caused by cracks in the brackets and the bottom of columns, forming plastic hinges. The most common seismic damage in precast industrial buildings is the damage of roof connections. Increasing the strength of roof connections can significantly improve the seismic performance of precast industrial buildings. Solution of vibration problem [2-10] has been the focus of industrial building design to be taken into consideration.

At present, there have been a lot of studies on the vibration reduction [11] and reinforcement of industrial building [12]. Reinforcement methods, reinforcement materials, and theories were various. For example, structural members were strengthened by FRP (fiber-reinforced polymer) material [13], columns and beams were reinforced by the enlarging section method, enclosed reinforced concrete method, enclosed steel plate method, etc. CA mortar was embedded in the floor layer to reduce the vibration effect [14]. Adding various damping devices [15-18], adding reinforced concrete column [19], and adding steel beam [20] or steel support were also commonly adopted methods in vibration attenuation engineering. In addition, there was a 
method in which industrial building is connected with auxiliary buildings [21], which can increase overall stiffness to achieve the vibration reduction effect, but this method has great influence on the site when there was no affiliated building. Due to limitation of existing equipment and pipelines and other additional devices and space, selection of reinforcement methods were often limited, which often requires comprehensive consideration, and at this time, influence of reinforcement on the original structure and space should be minimized.

For the reinforcement of multilayer industrial building, many factors need to be taken into consideration, such as reinforcement effect, disturbance to original structure, and economic effect. At present, main reinforcement methods commonly used in industrial building were as follows: enlargement section method, carbon fiber reinforcement method, prestress reinforcement method, energy dissipation method, outsourced steel method, additional support and unload method, etc. These methods can improve strength and stiffness of multilayer industrial building to varying degrees, however, they also have different limitations and shortcomings, especially reinforcement effect. There is no doubt that these methods have high efficiency in theory. However, because of structural complexity, construction error, connection between reinforced structure and original structure, etc., reinforcement effect in theory cannot be guaranteed. Therefore, in actual reinforcement engineering, reinforcement methods mentioned above have not been fully recognized and accepted, and it is urgent to explore a new reinforcement method.

In this paper, a new reinforcement method using a shortpier shear wall was put forward. Based on a practical multilayer industrial building with vibration problem, a three-dimensional finite element model of industrial building was established. Field test method was adopted to find out vibration cause, and new reinforcement method was used to strengthen multilayer industrial building. Structural response of multilayer industrial building before and after reinforcement was compared, reinforcement effect of new reinforcement method was verified, and new reinforcement method can provide reference for the reinforcement of multilayer industrial building with a similar structural configuration.

\section{New Reinforcement Method}

Industrial building is different from other structures, and many factors need to be taken into consideration. The details were as follows:

(1) Layout of machines: owing to space constraints, layout of machines was usually in a fixed range, which has a direct influence on reinforcement position

(2) Complicated pipeline layout: in most cases, pipeline layout cannot be changed, which limits the choice of the reinforcement method

(3) Demand for lighting: modern industrial building usually has a high requirement for lighting, and effect of strengthening on lighting of industrial building should be reduced as much as possible
(4) Influence on the original structure: effect of strengthening on the original structure should be reduced as much as possible

In actual engineering, the above factors need to be considered in a comprehensive way.

According to the characteristics of multilayer industrial buildings which are mostly framed structures, based on static and dynamic characteristics of frame structure, a new reinforcement method using a short-pier shear wall was put forward. Static and dynamic characteristics of industrial building were improved by short-pier shear walls, layout of short-pier shear wall is very flexible, and different reinforcement effects can be achieved according to the different layout of short-pier shear walls. At the same time, for the width of short-pier shear wall is small, it has less influence on the machine layout, pipeline layout, and lighting demand, and its influence on the original structure is small. Besides, construction error and connection between reinforced structure and original structure has less influence on the reinforcement effect. A photo of a short-pier shear wall is shown in Figure 1.

\section{General Situation of an Engineering Example}

3.1. Structural Survey. The main body of multilayer industrial building was a frame structure, length $\times$ width $\times$ height: $138.8 \mathrm{~m} \times 21.8 \mathrm{~m} \times 23.5 \mathrm{~m}$, it has a whole 3 layers and a local 4 layers, stiffness was mainly composed of frames, and three machines were located on the second floor. During the operation of machines, abnormal vibration appears in multilayer industrial building, especially the second floor, and vibration sensation was obvious. Three-dimensional view of multilayer industrial building is shown in Figure 2. The longitudinal section layout of multilayer industrial building is shown in Figure 3.

Based on vibration characteristics of multilayer industrial building and machines, continuous operation requirement of machines was taken into consideration, and working conditions were designed as follows: working condition one: $1 \#$ machine $100 \%$, 2\# machine 100\%, and 3\# machine $0 \%$, working condition two: $1 \#$ machine $100 \%$, 2\# machine $100 \%$, and $3 \#$ machine $50 \%$, working condition three: $1 \#$ machine $100 \%$, 2\# machine $100 \%$, and $3 \#$ machine $100 \%$, working condition four: $1 \#$ machine $50 \%$, 2\# machine $100 \%$, and $3 \# 100 \%$, working condition five: $1 \#$ machine $50 \%$, $2 \#$ machine $50 \%$, and $3 \#$ machine $100 \%$, and working condition six: $1 \#$ machine $100 \%$, 2\# machines $50 \%$, and $3 \#$ machine $50 \%$.

\subsection{Arrangement of Measuring Points. Arrangement of} measuring points should reflect vibration characteristics of industrial building and be simplified as much as possible. According to vibration characteristics of industrial building, five measuring points were arranged in field vibration experiment, they were arranged on the second floor (elevation value: $7.500 \mathrm{~m}$ ) where machines were installed. Measuring points from M1 to M4 were bidirectional vibration sensors, measuring point M5 was a three-directional vibration 


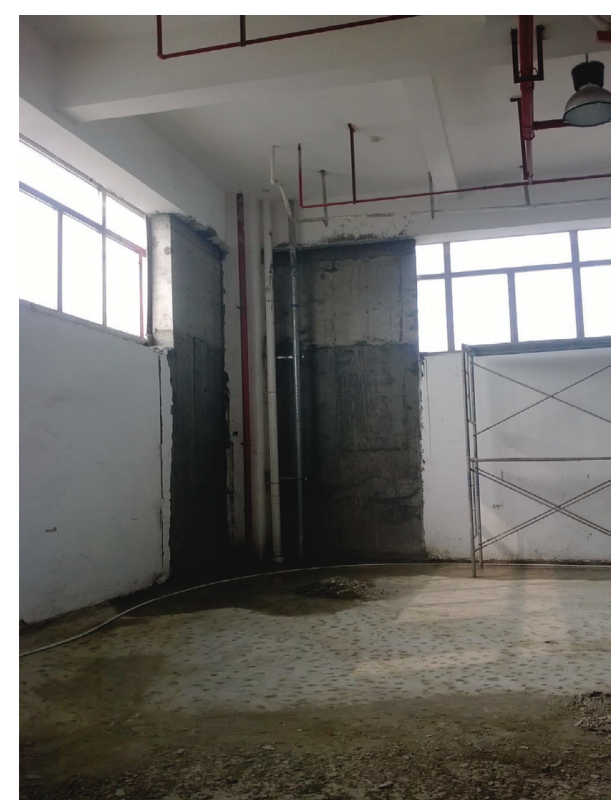

FIgUre 1: Photo of a short-pier shear wall.

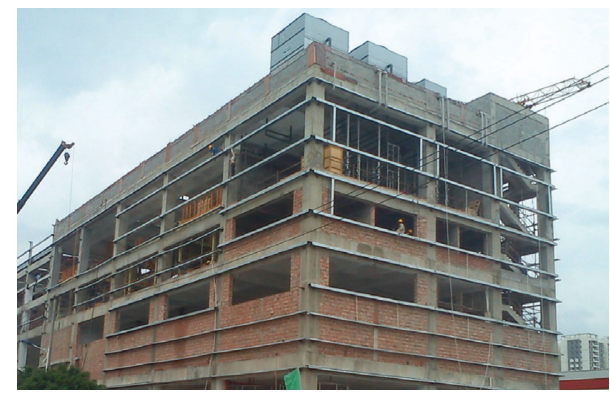

Figure 2: Three-dimensional view of industrial building.

sensor. The length direction of industrial building was set as $Y$ axis, the width direction of industrial building was set as $X$ axis, and the vertical direction of industrial building was set as $Z$ axis. Layout of measuring points is shown in Figure 4. Sensors in industrial building are shown in Figure 5, and sensor in machine is shown in Figure 6.

3.3. Finite Element Model. In order to determine the layout of a short-pier shear wall and calculate the reinforcement effect, three-dimensional finite element models of industrial building before and after reinforcement were built by ANSYS software. Frame structures were simulated by beam 189 element, short-pier shear walls were simulated by shell63 element, and machines and additional mass were simulated by mass 21 element.

In the finite element model, for C30 concrete, density was $2500 \mathrm{~kg} / \mathrm{m}^{3}$, elasticity modulus was $3 \times 10^{10} \mathrm{~Pa}$, and Poisson's ratio was 0.2 . For C35 concrete, density was $2500 \mathrm{~kg} / \mathrm{m}^{3}$, elasticity modulus was $3.15 \times 10^{10} \mathrm{~Pa}$, and Poisson's ratio was 0.2 . For filled wall composed of porous shale bricks, density was $1800 \mathrm{~kg} / \mathrm{m}^{3}$, elasticity modulus was $0.9 \times 10^{10} \mathrm{~Pa}$, and Poisson's ratio was 0.2 . For masonry composed of small concrete hollow blocks, density was $1204 \mathrm{~kg} / \mathrm{m}^{3}$, elasticity modulus was $0.4 \times 10^{10} \mathrm{~Pa}$, and Poisson's ratio was 0.2 . C30 concrete was used for columns with elevation over $14.000 \mathrm{~m}, \mathrm{C} 35$ concrete was used for columns with elevation below $14.000 \mathrm{~m}$, and C30 concrete was used for all beams.

The length direction of industrial building was $X$ axis, the width direction of industrial building was $Y$ axis, the vertical direction of industrial building was $Z$ axis, fixed-end constraints were adopted at the bottom of industrial building. The finite element model of industrial building is shown in Figure 7.

After the finite element model of multilayer industrial building was built, based on test results of multilayer industrial building before reinforcement, the finite element model was modified. The first order frequencies of the measured values were $2.45 \mathrm{~Hz}$ in the $X$ direction and $2.94 \mathrm{~Hz}$ in the $Y$ direction. The first order frequencies in the $X$ direction and $Y$ direction of the finite element model were $2.02 \mathrm{~Hz}$ and $3.07 \mathrm{~Hz}$, respectively. The ratios of calculated frequencies to measured frequencies were 0.82 and 1.04, respectively, which were basically in line with the actual situation. Natural frequencies and vibration modes of finite element model were consistent with measured values, which can be used for calculation and comparison of the reinforcement effect.

\section{Construction of the New Reinforcement Method}

According to the formula of frequency calculation, frequency is related to stiffness and mass. The short-pier shear wall increases the stiffness of the structure. Although it also increases the weight of structure, stiffness contributes more to the frequency, as a result, the frequency of the structure increases, and the energy dissipation capacity increases. Based on vibration characteristics of industrial building, according to field investigation of industrial building, possible layout positions of the short-pier shear wall were marked out. A preliminary strengthening scheme was put forward, and reinforcement effect of preliminary strengthening scheme was calculated by ANSYS software. If expected reinforcement effect was not achieved, the layout of short-pier shear wall should be adjusted, and corresponding reinforcement scheme should be calculated by ANSYS software again, and after several adjustments, final reinforcement scheme was determined. Due to the complex structure of multilayer industrial buildings, the location and number of short-pier shear walls were numerous and limited by the length of components, only part of the layout of short-leg shear walls was shown. Part of the short-pier shear wall layout is shown in Figure 8.

The short-pier shear wall was connected with the original structure by common joints. It was assumed that the shortpier shear wall can play a better role in connection with the original structure. Finite element analysis of reinforcement schemes was made. Forced vibration frequency of machine in the $Y$ direction was $2.96 \mathrm{~Hz}$, and it was in resonance range with unreinforced industrial building in the $Y$ direction. After multilayer industrial building was strengthened by 


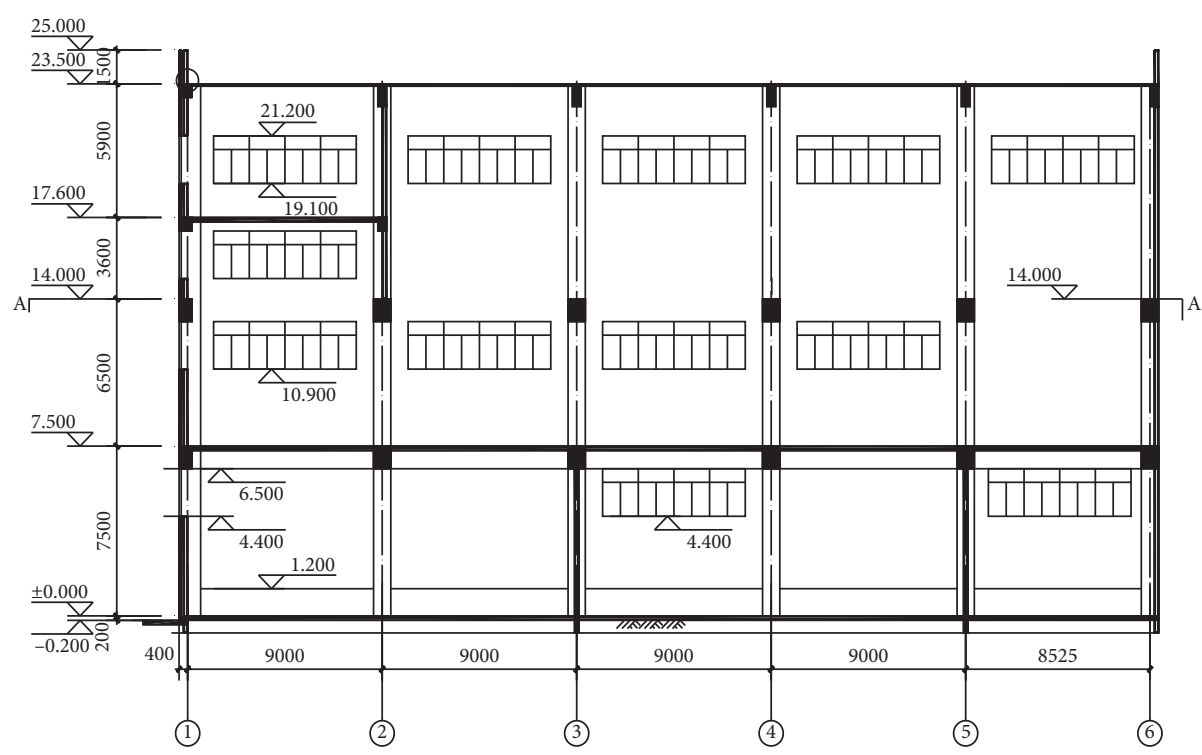

FIgURE 3: Longitudinal section layout of industrial building.

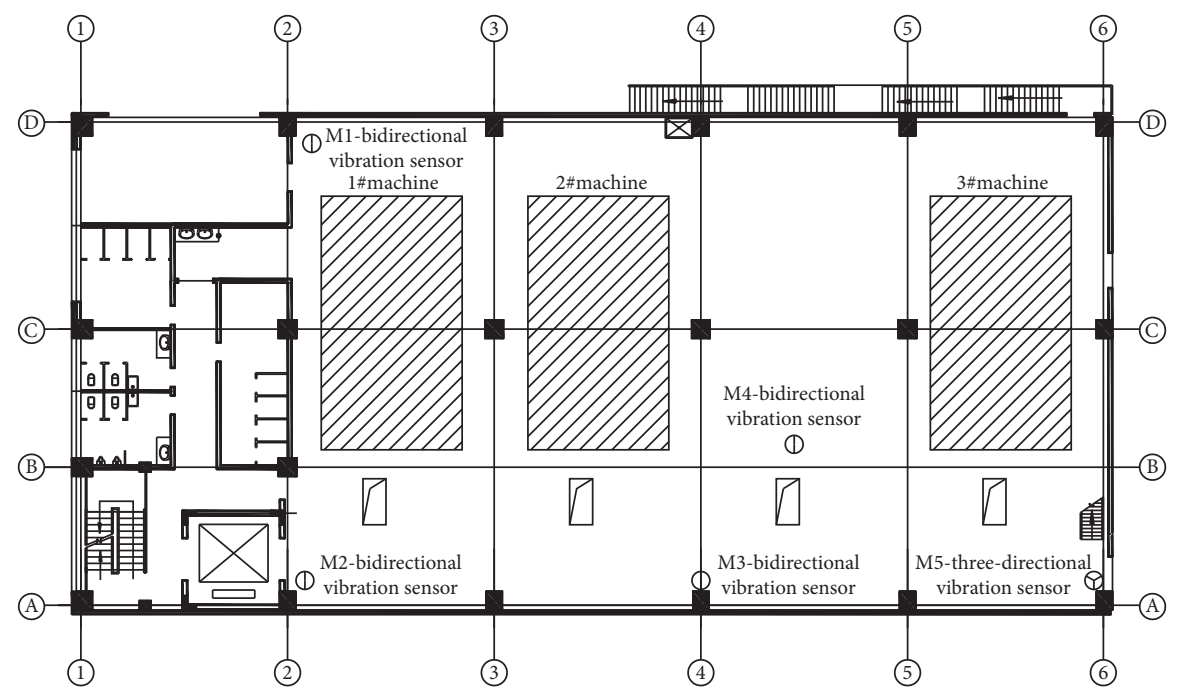

FIgURE 4: Plane layout of measuring points.

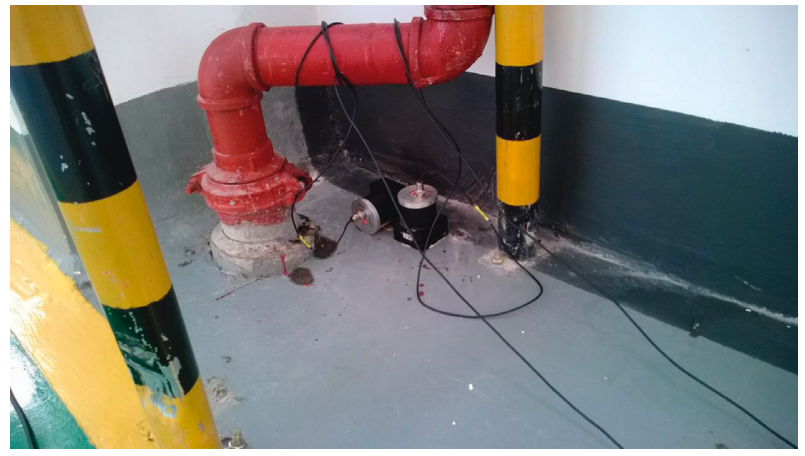

FIGURE 5: Sensors in industrial building.

short-pier shear walls, the first order natural frequency, the second order natural frequency, and the third order natural frequency of industrial building were $4.56 \mathrm{~Hz}, 4.57 \mathrm{~Hz}$,

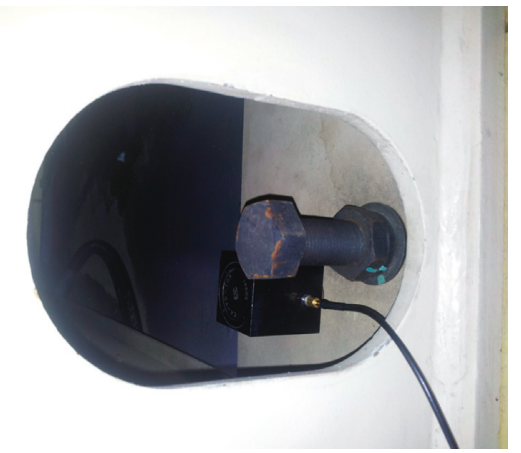

Figure 6: Sensor in the machine.

$4.36 \mathrm{~Hz}$, respectively. They were not in resonance range with the machine in the $Y$ direction, and reinforcement effects of reinforcement scheme can meet reinforcement requirement. 


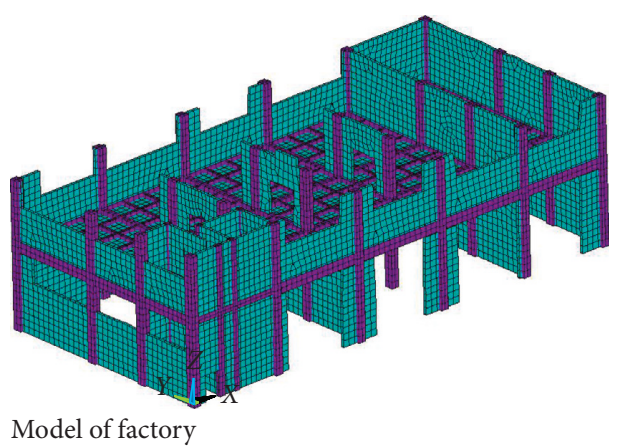

Figure 7: Finite element model of industrial building.

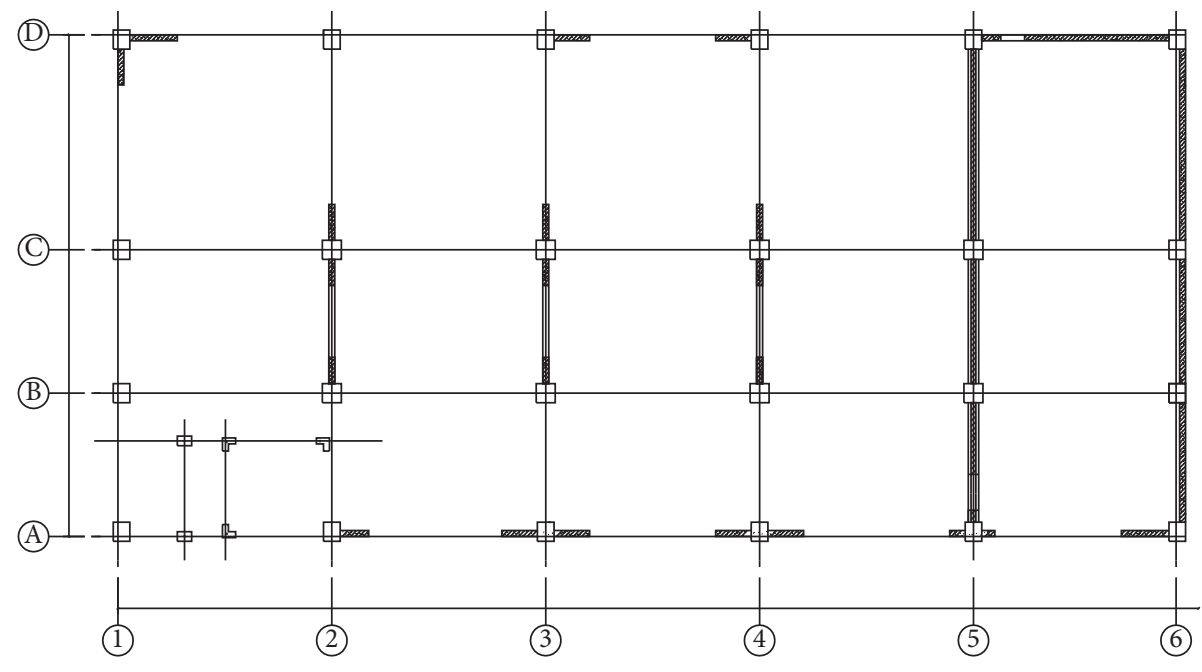

Short-pier shear wall

Figure 8: Part of the short-pier shear wall layout.

Construction photos of new reinforcement method are shown in Figures 9 and 10.

\section{Experimental Results}

5.1. Experimental Results before Reinforcement. For vibration characteristics of multilayer industrial building before reinforcement, field vibration tests for six designed working conditions were carried out, and statistical analysis for acceleration and velocity data of five measuring points in six working conditions was made. Under the action of various working conditions, peak acceleration values of the $Y$ direction and $Z$ direction are summarized in Figure 11. Peak velocity values of the $Y$ direction and $Z$ direction are summarized in Figure 12, and peak accelerations and velocities in the $X$ direction of measuring point 5 under various working conditions are shown in Table 1.

Self-vibration characteristics of machine and industrial building are shown in Table 2. Vibration frequencies between three machines and industrial building were very close in the $X$ direction and $Y$ direction. Vibration test curves of machines and multilayer industrial building were analyzed.
Abnormal vibration cause of industrial building was analyzed, based on the standard of structural vibration sensitivity, human body feeling was unbearable when vibration acceleration was more than $1.5 \mathrm{~m} / \mathrm{s}^{2}$. Test results were statistically analyzed as follows:

(1) Analysis of acceleration results: based on Figure 11 and Table 1, peak acceleration values in the $X$ direction and $Y$ direction of industrial building were $0.800 \mathrm{~m} / \mathrm{s}^{2}$ and $2.409 \mathrm{~m} / \mathrm{s}^{2}$, respectively, and they were all at measuring point 5 of working condition 4 . Peak acceleration value in the $Z$ direction was $0.717 \mathrm{~m} / \mathrm{s}^{2}$, and it is at measuring point 4 of working condition 1. Peak acceleration values in the $X$ direction were all in grade IV. $26.67 \%$ percent of peak acceleration in the $Y$ direction was in grade III, $53.33 \%$ percent of peak acceleration in the $Y$ direction was in grade IV, $20 \%$ percent of peak acceleration in the $Y$ direction was in grade V. 3.33\% percent of peak acceleration in the $Z$ direction was in grade II, $66.67 \%$ percent of peak acceleration in the $Z$ direction was in grade III, and $30.00 \%$ percent of peak acceleration in the $Z$ direction was in grade IV. 


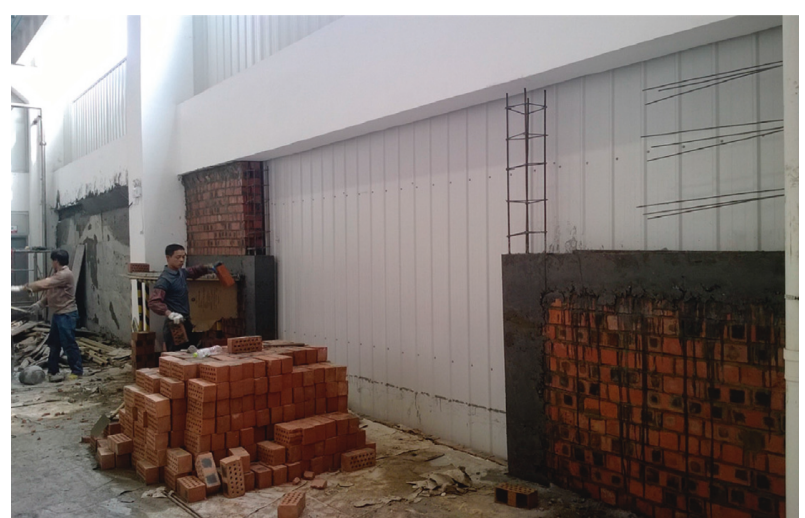

FIGURE 9: Short-pier shear walls in construction.

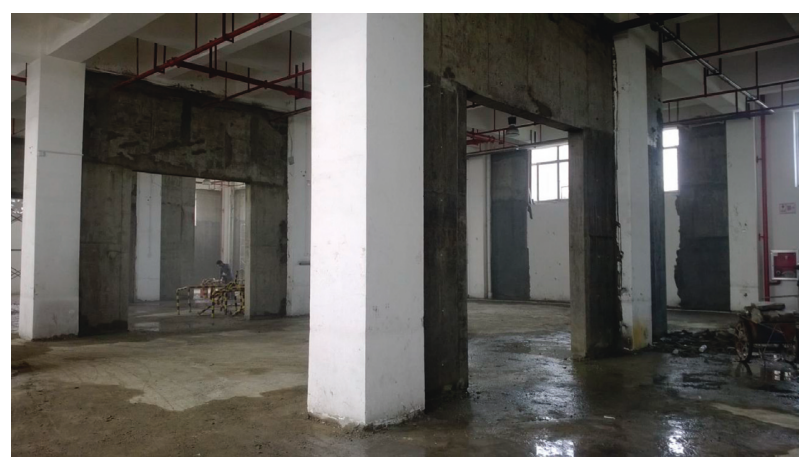

Figure 10: View of short-pier shear walls.

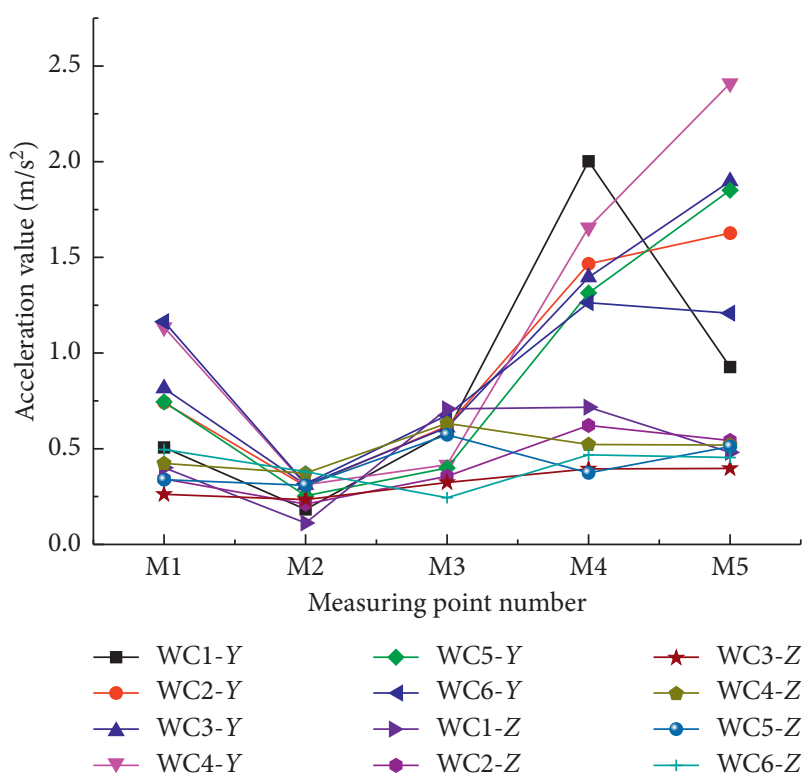

Figure 11: Peak acceleration values in $Y$ and $Z$ directions.

In conclusion, $20 \%$ percent of acceleration values in the $Y$ direction of industrial building have exceeded human body's tolerance feeling, and the $Y$ direction of industrial building should be the focus of reinforcement.

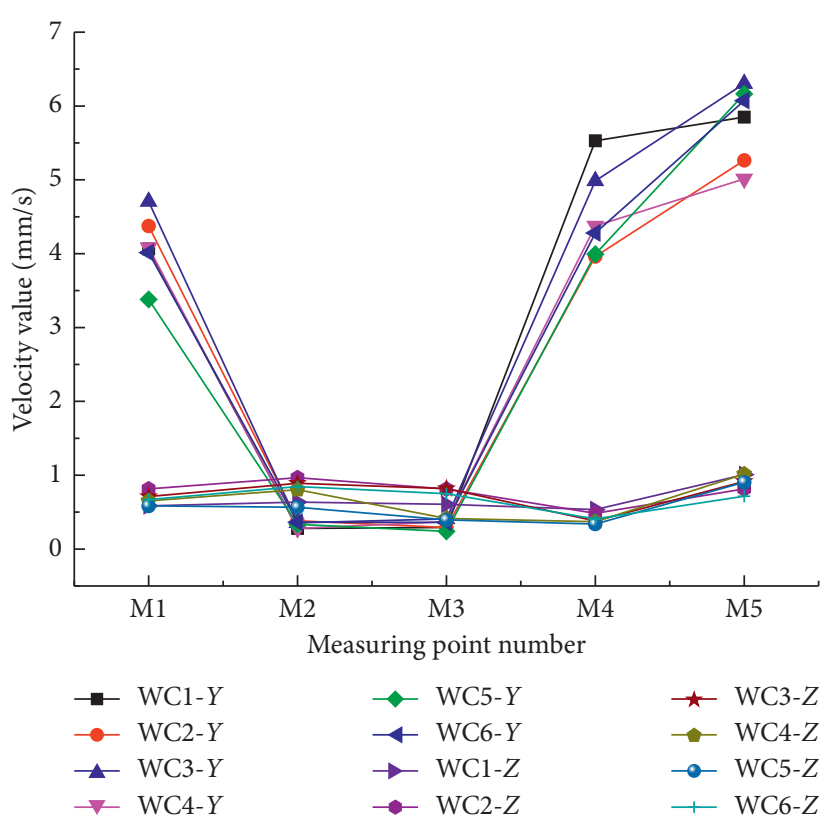

Figure 12: Peak velocity values in $Y$ and $Z$ directions.

TABle 1: Peak accelerations and peak velocities of $X$ direction at point 5 .

\begin{tabular}{lcccccc}
\hline Working condition & $\begin{array}{c}\text { WC- } \\
1\end{array}$ & $\begin{array}{c}\text { WC- } \\
2\end{array}$ & $\begin{array}{c}\text { WC- } \\
3\end{array}$ & $\begin{array}{c}\text { WC- } \\
4\end{array}$ & $\begin{array}{c}\text { WC- } \\
5\end{array}$ & $\begin{array}{c}\text { WC- } \\
6\end{array}$ \\
\hline $\begin{array}{l}\text { Acceleration } \\
\left(\mathrm{m} / \mathrm{s}^{2}\right)\end{array}$ & 0.772 & 0.566 & 0.582 & 0.8 & 0.789 & 0.673 \\
Velocity (mm/s) & 4.09 & 3.306 & 3.332 & 3.32 & 3.519 & 2.752 \\
\hline
\end{tabular}

TABLE 2: Test results of self-vibration characteristics for machines and industrial building.

\begin{tabular}{lcccc}
\hline Direction & \multicolumn{4}{c}{ Natural vibration frequency value } \\
& $\begin{array}{c}\text { Industrial } \\
\text { building }\end{array}$ & $\begin{array}{c}1 \# \\
\text { machine }\end{array}$ & $\begin{array}{c}2 \# \\
\text { machine }\end{array}$ & $\begin{array}{c}3 \# \\
\text { machine }\end{array}$ \\
\hline$X$ & 2.94 & 2.75 & 2.86 & 2.72 \\
$Y$ & 2.45 & 2.96 & 2.94 & 2.94 \\
$Z$ & 10.28 & 45.24 & 46.99 & 42.05 \\
\hline
\end{tabular}

(2) Analysis of velocity results: based on Figure 12 and Table 1, peak velocity value in the $X$ direction was $4.09 \mathrm{~mm} / \mathrm{s}$ at measuring point 5 of working condition 1 . Peak velocity value in the $Y$ direction was $6.302 \mathrm{~mm} / \mathrm{s}$ at measuring point 5 of working condition 3 . Peak velocity value in the $Z$ direction was $1.014 \mathrm{~mm} / \mathrm{s}$ at measuring point 5 of working condition 4. According to specification requirement [22], velocity values in $X, Y$, and $Z$ directions meet specification requirements, but velocity of the $Y$ direction was $6.302 \mathrm{~mm} / \mathrm{s}$, it was close to the allowable value $6.4 \mathrm{~mm} / \mathrm{s}$ of the specification limit. In conclusion, stiffness of multilayer industrial building in the $Y$ direction was weak, and it should be the focus of reinforcement. 
TABLE 3: Natural frequencies comparison before and after reinforcement.

\begin{tabular}{lccccc}
\hline \multirow{2}{*}{ Direction } & \multicolumn{3}{c}{ Natural frequencies $(\mathrm{Hz})$} & Unreinforced industrial building (Hz) & Reinforced industrial building (Hz) \\
& 1\# machine & 2\# machine & 3\# machine & & 7.83 \\
$X$ & 2.75 & 2.86 & 2.72 & 2.94 & 5.87 \\
$Y$ & 2.96 & 2.94 & 2.94 & 2.45 & 10.77 \\
$Z$ & 45.24 & 46.99 & 42.05 & 10.28 & 10.77 \\
\hline
\end{tabular}

TABLE 4: Comparison of maximum acceleration and maximum velocity before and after reinforcement.

\begin{tabular}{lcccc}
\hline Direction & $\begin{array}{c}\text { Maximum acceleration before } \\
\text { reinforcement }\end{array}$ & $\begin{array}{c}\text { Maximum acceleration after } \\
\text { reinforcement }\end{array}$ & $\begin{array}{c}\text { Maximum velocity before } \\
\text { reinforcement }\end{array}$ & $\begin{array}{c}\text { Maximum velocity after } \\
\text { reinforcement }\end{array}$ \\
\hline$X$ & 0.800 & 0.765 & 4.090 & 1.666 \\
$Y$ & 2.409 & 1.162 & 6.302 & 3.012 \\
$Z$ & 0.717 & 1.536 & 1.014 & 1.813 \\
\hline
\end{tabular}

(3) Analysis of self-vibration characteristics: based on Table 2, vibration frequency of the machine was close to vibration frequency of multilayer industrial building in the $X$ direction and $Y$ direction, and the corresponding ratio $f_{1} / f_{2}=0.75 \sim 1.25$ was in resonance range.

In conclusion, based on test results and analysis of acceleration and velocity and self-vibration characteristics, it can be concluded that abnormal vibration of industrial building was caused by resonance between machines and multilayer industrial building.

5.2. Experimental Results after Reinforcement. After multilayer industrial building was strengthened by a new reinforcement method, vibration characteristics of industrial building were tested again, and measuring point layout and working condition design were the same as those before reinforcement. Experimental results were as follows.

5.2.1. Self-Vibration Characteristic. Vibration frequencies of industrial building before and after reinforcement are shown in Table 3, and it was shown that stiffness of reinforced industrial building in the $X$ direction and $Y$ direction was significantly improved. Compared with natural frequencies of three machines in the direction of $X, Y$, and $Z$, natural frequencies of industrial building were not in resonance range with machines in three directions. Based on field test results and field sense, the reinforcement effect was good.

5.2.2. Vibration Characteristic. The maximum acceleration and velocity before and after reinforcement are shown in Table 4, and the maximum acceleration and velocity before and after reinforcement of the $X$ direction at measuring point 5 are shown in Table 5 . The maximum velocity and maximum acceleration of the $Y$ direction in industrial building were improved to varying degrees, and vibration characteristics of industrial building were significantly improved.

In conclusion, according to test results of peak acceleration values, peak velocity values, and self-vibration characteristics before and after reinforcement, the short-pier shear wall reinforcement method was scientific and reasonable. It can significantly improve stiffness and vibration characteristics of multilayer industrial building and avoid resonance between machines and multilayer industrial building.

\section{Discussion}

Industrial building was strengthened by short-pier shear walls, division and content of working conditions for reinforced multilayer industrial building were the same as those before reinforcement. Peak acceleration of the $Y$ direction and $Z$ direction is shown in Figure 13, peak velocity of the $Y$ direction and $Z$ direction at measuring point 5 is shown in Figure 14, and peak acceleration and peak velocity in the $X$ direction are shown in Table 6 .

Based on Figures 13 and 14 and Table 6, statistical analysis of test results after reinforcement were shown as follows:

(1) Acceleration results: the maximum acceleration value of industrial building in the $X$ direction was $0.765 \mathrm{~m} / \mathrm{s}^{2}$ at measuring point 5 of working condition 3. The maximum acceleration value of industrial building in the $Y$ direction was $1.162 \mathrm{~m} / \mathrm{s}^{2}$ at measuring point 2 of working condition 3 . The maximum acceleration value of industrial building in the $Z$ direction was $1.536 \mathrm{~m} / \mathrm{s}^{2}$ at measuring point 3 of working condition 3. $16.67 \%$ percent of peak acceleration values in the $X$ direction of industrial building were in grade III, $83.33 \%$ percent of peak acceleration values of industrial building in the $X$ direction were in grade IV. $36.67 \%$ percent of peak acceleration values of industrial building in the $Y$ direction were in grade III, $63.33 \%$ percent of peak acceleration values of industrial building in the $Y$ direction were in grade IV. $33.33 \%$ percent of peak acceleration values of industrial building in the $Z$ direction were in grade III, $63.34 \%$ percent of peak acceleration values of industrial building in the $Z$ direction were in grade IV, and $3.33 \%$ percent of peak acceleration values of industrial building in the 
TABle 5: Peak value of acceleration and velocity in the $X$ direction at measuring point 5.

\begin{tabular}{|c|c|c|c|c|c|c|}
\hline Working condition & WC-1 & WC-2 & WC-3 & WC-4 & WC-5 & WC-6 \\
\hline Acceleration before reinforcement $\left(\mathrm{m} / \mathrm{s}^{2}\right)$ & 0.772 & 0.566 & 0.582 & 0.8 & 0.789 & 0.673 \\
\hline Acceleration after reinforcement $\left(\mathrm{m} / \mathrm{s}^{2}\right)$ & 0.464 & 0.673 & 0.765 & 0.699 & 0.757 & 0.607 \\
\hline Velocity before reinforcement $\left(\mathrm{m} / \mathrm{s}^{2}\right)$ & 4.09 & 3.306 & 3.332 & 3.32 & 3.519 & 2.752 \\
\hline Velocity after reinforcement $\left(\mathrm{m} / \mathrm{s}^{2}\right)$ & 0.819 & 1.429 & 1.546 & 1.666 & 1.521 & 1.277 \\
\hline
\end{tabular}

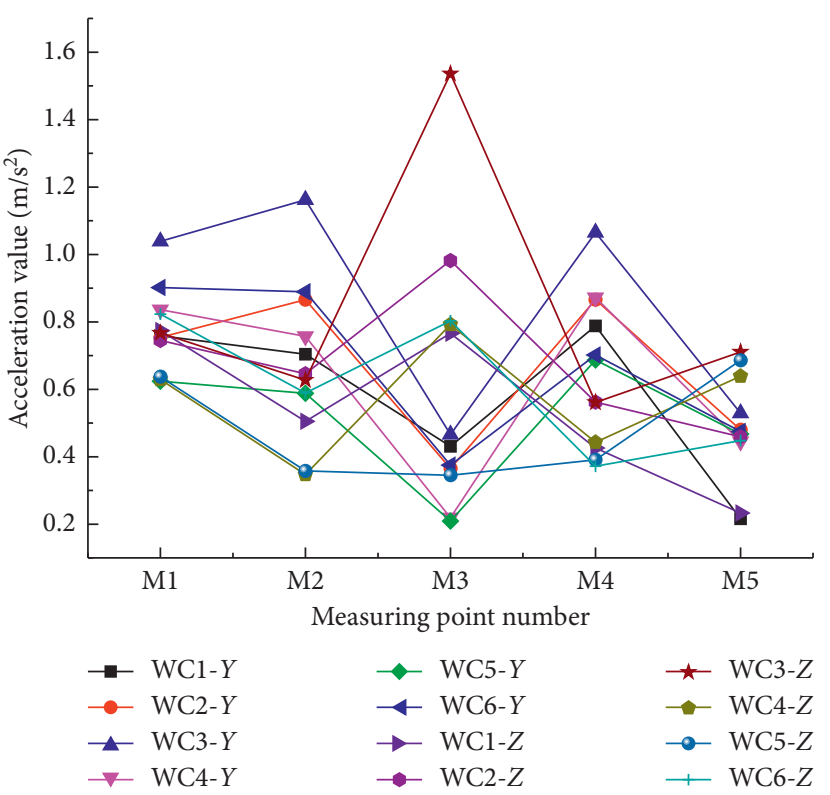

FIgURE 13: Peak accelerations.

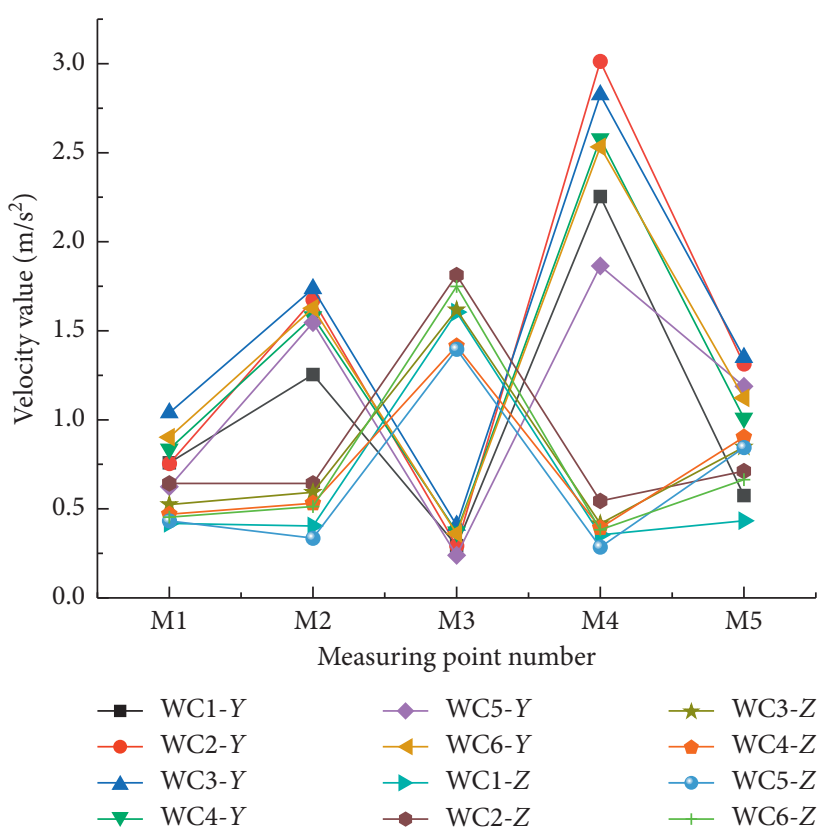

FIgURe 14: Peak velocities at measuring point 5.

$Z$ direction were in grade $\mathrm{V}$. In conclusion, acceleration vibration characteristics of three directions of industrial building were improved.
TABLE 6: Peak acceleration and peak velocity in the $X$ direction.

\begin{tabular}{lcccccc}
\hline Working condition & WC- & WC- & WC- & WC- & WC- & WC- \\
& 1 & 2 & 3 & 4 & 5 & 6 \\
\hline $\begin{array}{l}\text { Acceleration } \\
\left(\mathrm{m} / \mathrm{s}^{2}\right)\end{array}$ & 0.464 & 0.673 & 0.765 & 0.699 & 0.757 & 0.607 \\
Velocity $\left(\mathrm{m} / \mathrm{s}^{2}\right)$ & 0.819 & 1.429 & 1.546 & 1.666 & 1.521 & 1.277 \\
\hline
\end{tabular}

(2) Velocity results: the maximum velocity value of industrial building in the $X$ direction was $1.666 \mathrm{~mm} / \mathrm{s}$ at measuring point 5 of working condition 4 . The maximum velocity value of industrial building in the $Y$ direction was $3.012 \mathrm{~mm} / \mathrm{s}$ at measuring point 4 of working condition 2 . The maximum velocity value of industrial building in the $Z$ direction was $1.813 \mathrm{~mm} / \mathrm{s}$ at measuring point 3 of working condition 2 . According to specification requirements, vibration velocity values of three directions of industrial building meet the requirements, especially vibration velocity of the $Y$ direction in industrial building. In conclusion, velocity vibration characteristics of three directions of industrial building were improved.

(3) Self-vibration characteristics: first order natural frequency in the $X$ direction of industrial building before reinforcement was $2.94 \mathrm{~Hz}$. First order natural frequency in the $Y$ direction of industrial building before reinforcement was $2.45 \mathrm{~Hz}$. First order natural frequency in the $Z$ direction of industrial building before reinforcement was $10.28 \mathrm{~Hz}$. First order natural frequency in the $X$ direction of industrial building after reinforcement was $7.83 \mathrm{~Hz}$. First order natural frequency in the $Y$ direction of industrial building after reinforcement was $5.87 \mathrm{~Hz}$. First order natural frequency in the $Z$ direction of industrial building after reinforcement was $10.77 \mathrm{~Hz}$. Comparison of test results showed that strength and stiffness of industrial building were significantly improved.

\section{Conclusions}

A new reinforcement method using a short-pier shear wall was put forward. Based on the vibration test results of a practical multilayer industrial building before reinforcement, a three-dimensional finite element model of industrial building was established, which has been bverified by tests. It provides a reference finite element model for the design and selection of reinforcement schemes and was used for the analysis and comparison of reinforcement effects. The field test method was adopted to find out vibration 
cause, and the new reinforcement method was used to strengthen multilayer industrial building, structural response of multilayer industrial building before and after reinforcement was compared, and conclusions were as follows:

(1) After machines were installed in multilayer industrial building, resonance between machines and industrial building was the main reason of abnormal vibration in multilayer industrial building. Resonance problem should be given enough attention in the design of multilayer industrial building.

(2) A new reinforcement method using a short-pier shear wall can improve strength, stiffness, and dynamic characteristics of multilayer industrial building significantly. After reinforcement, natural frequency of industrial building in the $Y$ direction was enhanced from $2.45 \mathrm{~Hz}$ to $5.87 \mathrm{~Hz}$, and natural frequency of industrial building in the $X$ direction was enhanced from $2.94 \mathrm{~Hz}$ to $7.83 \mathrm{~Hz}$. They were not in resonance range with machine whose natural frequency was $2.94 \mathrm{~Hz}$ in the width direction. Vibration characteristics of industrial building were improved to varying degrees, and after reinforcement, the maximum acceleration in the $X$ direction decreases by $4.38 \%$, the maximum acceleration in the $Y$ direction decreases by $51.76 \%$, and the maximum acceleration in the $Z$ direction increases by $114.23 \%$. The expected reinforcement effect was obtained.

In conclusion, it was scientific and reasonable to strengthen multilayer industrial building by the short-pier shear wall. Compared with other reinforcement methods, the new reinforcement method put forward in this paper has many advantages, which can provide reference for the reinforcement of multilayer industrial building with a similar structural configuration.

\section{Data Availability}

The data used to support the findings of this study are included within the article.

\section{Conflicts of Interest}

The authors declare that there are no conflicts of interest regarding the publication of this paper.

\section{Acknowledgments}

The authors thank the National Natural Science Foundation of China (grant nos. 51738004, 51868007, 51368005, and 51878186), Guangxi Science and Technology Project (project no. AD17195096), and Sichuan Science and Technology Program Funding (no. 2018GZ0052).

\section{References}

[1] A. M. Aly, E. Dragomirescu, J. M. Xie, and M. A. HaririArdebili, "Vibration and control in structures under single and multiple hazards," Shock And Vibration, vol. 2017, Article ID 1814286, 2 pages, 2017.
[2] C. Zou, J. A. Moore, M. Sanayei, and Y. Wang, "Impedance model for estimating train-induced building vibrations," Engineering Structures, vol. 172, pp. 739-750, 2018.

[3] C. Zou, Y. Wang, J. A. Moore, and M. Sanayei, "Train-induced field vibration measurements of ground and over-track buildings," Science of the Total Environment, vol. 575, pp. 1339-1351, 2017.

[4] D. De Domenico and G. Ricciardi, "Earthquake-resilient design of base isolated buildings with TMD at basement: application to a case study," Soil Dynamics and Earthquake Engineering, vol. 113, pp. 503-521, 2018.

[5] D. De Domenico and G. Ricciardi, "An enhanced base isolation system equipped with optimal tuned mass damper inerter (TMDI)," Earthquake Engineering \& Structural Dynamics, vol. 47, no. 5, pp. 1169-1192, 2018.

[6] D. De Domenico, N. Impollonia, and G. Ricciardi, "Seismic retrofitting of confined masonry-RC buildings: the case study of the university hall of residence in Messina, Italy," Ingegneria Sismica, vol. 36, no. 1, pp. 54-85, 2019.

[7] A. Belleri, E. Brunesi, R. Nascimbene, M. Pagani, and P. Riva, "Seismic performance of precast industrial facilities following major earthquakes in the Italian territory," Journal of Performance of Constructed Facilities ASCE, vol. 29, no. 5, Article ID 04014135, 2015.

[8] E. Brunesi, R. Nascimbene, D. Bolognini, and D. Bellotti, "Experimental investigation of the cyclic response of reinforced precast concrete framed structures," PCI Journal, vol. 60, no. 2, pp. 57-79, 2015.

[9] Y. T. Choi and N. M. Wereley, "Shock isolation systems using magnetorheological dampers," Journal of Vibration and Acoustics, vol. 130, no. 2, pp. 111-120, 2008.

[10] L. N. Virgin and R. B. Davis, "Vibration isolation using buckled struts," Journal of Sound and Vibration, vol. 260, no. 5, pp. 965-973, 2003.

[11] P. F. Guo, Z. Q. Lang, and Z. K. Peng, "Analysis and design of the force and displacement transmissibility of nonlinear viscous damper based vibration isolation systems," Nonlinear Dynamics, vol. 67, no. 4, pp. 2671-2687, 2012.

[12] F. Fraternali, G. Carpentieri, M. Modano, F. Fabbrocino, and R. E. Skelton, "A tensegrity approach to the optimal reinforcement of masonry domes and vaults through fiberreinforced composite materials," Composite Structures, vol. 134, pp. 247-254, 2015.

[13] M. A. Aiello, F. Micelli, and L. Valente, "Structural upgrading of masonry columns by using composite reinforcements," Journal of Composites for Construction, vol. 11, no. 6, pp. 650-658, 2007.

[14] Q. H. Li, J. G. Xiang, J. L. Liu et al., "Construction of damping performance of CA mortar in multilayer plant floor layer," Construction Technology, vol. 42, no. 16, pp. 61-63, 2013.

[15] M. Gharib and M. Karkoub, "A comparative study of mass based vibration dampers," in Proceedings of the ASME 2017 International Mechanical Engineering Congress and Exposition, vol. 4A, Salt Lake City, UT, USA, November 2017.

[16] H. E. Kalehsar and N. Khodaie, "Wind-induced vibration control of super-tall buildings using a new combined structural system," Journal of Wind Engineering and Industrial Aerodynamics, vol. 172, pp. 256-266, 2018.

[17] D. D. Domenico and G. Ricciardi, "Earthquake protection of existing structures with limited seismic joint: base isolation with supplemental damping versus rotational inertia," Advances in Civil Engineering, vol. 2018, Article ID 6019495, 24 pages, 2018. 
[18] H. Zhao, W. G. Liu, S. Zhong et al., "Testing and design research of vibration of an industrial factory building," Structural Engineers, vol. 32, no. 1, pp. 119-126, 2016.

[19] F. Y. Wang, S. Li, and N. Xiao, "Dynamic analysis and treatment of vibration reduction for A broken floor in thermal power plant," Earthquake Resistant Engineering and Retrofitting, vol. 33, no. 3, pp. 70-74, 2011.

[20] C. Y. Shen, F. L. Zhou, P. Tan et al., "Vibration reduction and strengthening of a multilayer reinforced concrete frame factory building," World Earthquake Engineering, vol. 21, no. 2, pp. 7-12, 2005.

[21] Z. Y. Ma, C. N. Shen, and Y. B. Wang, "Studies on the antivibration and reinforcement of powerhouse in Hongshi hydropower station," Journal of Hydroelectric Engineering, vol. 21, no. 1, pp. 28-36, 2002, in Chinese.

[22] Ministry of Metallurgical Industry of the PRC, Vibration Calculation and Vibration Isolation Design Rules for LoadBearing Structures of Buildings under Dynamic Loads (YBJ 5590 YSJ 009-90), Metallurgical Industry Press, Beijing, China, 1990. 


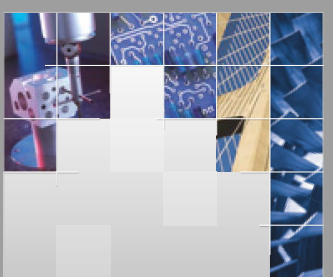

\section{Enfincering}
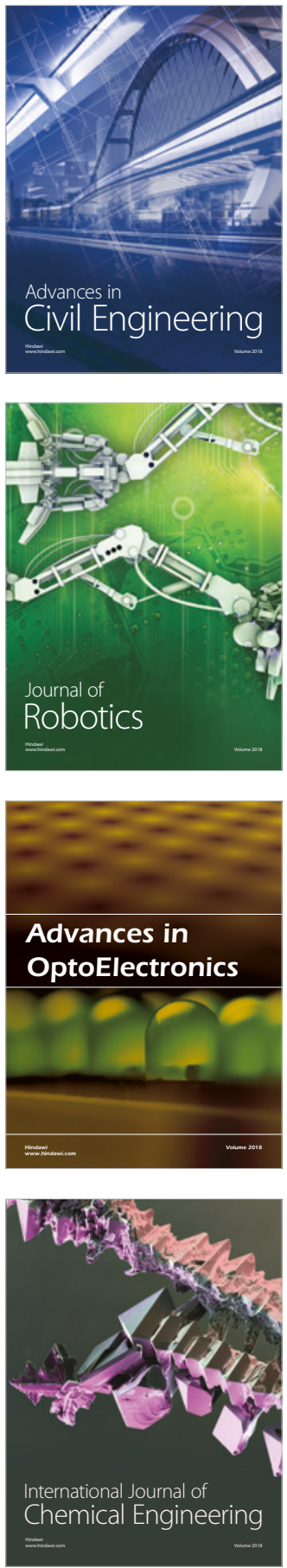

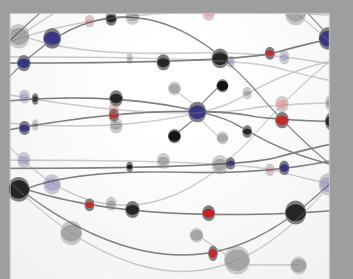

\section{Rotating \\ Machinery}

The Scientific World Journal

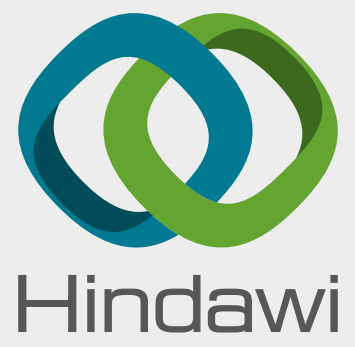

Submit your manuscripts at

www.hindawi.com
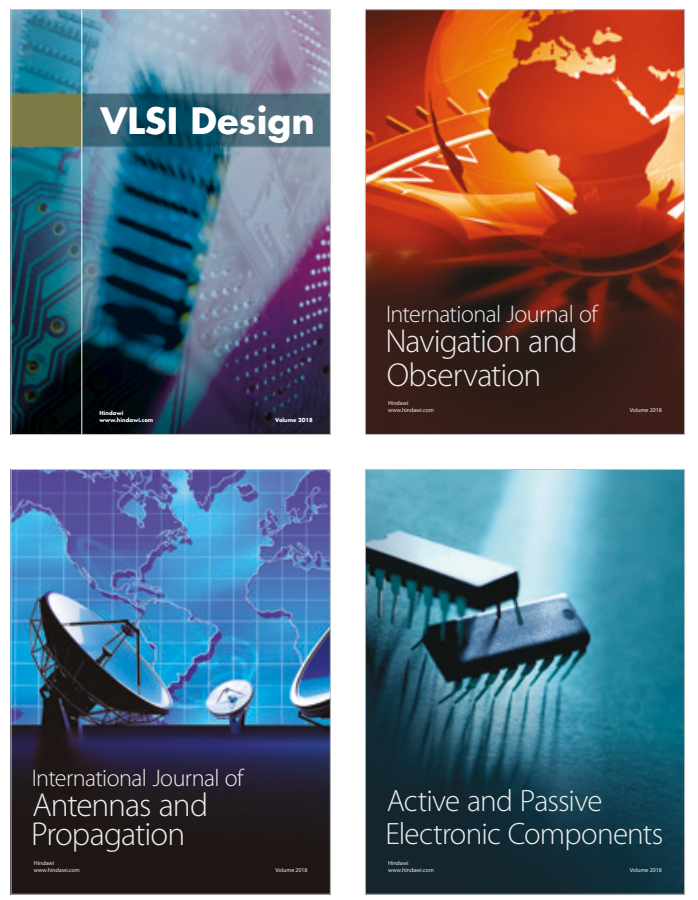
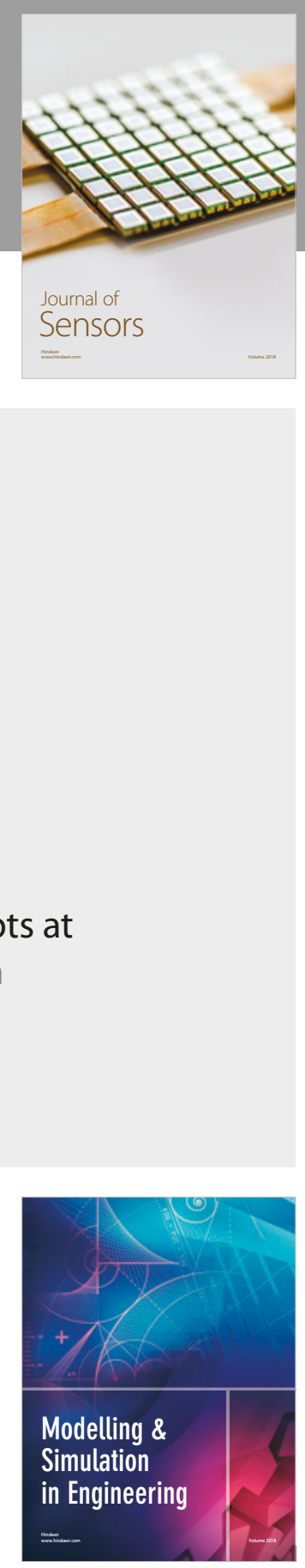

\section{Advances \\ Multimedia}
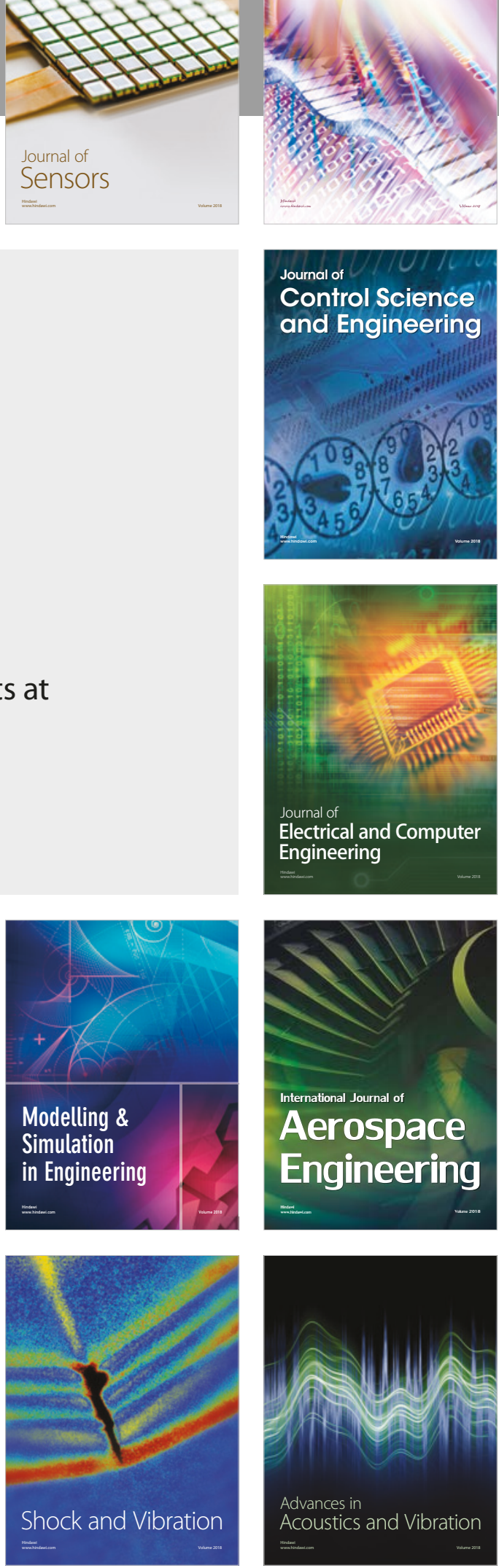